\title{
European Most Innovative Universities
}

\subsection{Introduction to Ranking}

In ranking of 2018 European Most Innovative Universities for the year 2018, Belgian University of KU Leuven topped the list, becoming the first innovative university in Europe for the third year in a row, among the universities that work on the advancement of science, development of modern technologies, and support of industries and markets. It should be noted that this University, established in 1425, offers its programs in Dutch. Then comes Imperial College London in the second place and Cambridge University in the third, maintaining their ranking for the third year in a row. However, the ranks of some other universities have changed in 2017 and 2018 lists.

Although the number of listed German universities (23 universities) has not changed in 2017 and 2018, many of them have achieved better ranks in the 2018 list. Cumulatively, it can be said that they are collectively 23 ranks up, which is the greatest progress achieved by a European country in the list. British universities have increased from 17 in 2017 to 21 in 2018, but cumulatively they have dropped 35 places against universities from other countries. Perhaps, the most obvious reason behind this is the withdrawal of the UK from the European Union, briefly expressed as "Brexit". Although it is still under discussion and will take time to be finalized, it may lead some scientists to move from Britain to other European countries. A study undertaken in February 2018 by Center for Global Higher Education, headquartered in UK, suggests that many German universities consider the Brexit as an advantage, for it enables German universities to attract British researchers. Meanwhile, the study suggests that academic staff in the UK complain about the fewer number of British postdocs who have already started to look for jobs in the European Union or the USA, something that is expected to get worse upon Brexit. A study undertaken in November 2017 by School of International Futures for the Royal Society in the UK predicts that British universities will compete for fewer qualified workers and projects that used to receive European funds. British researchers invited to contribute to joint research projects and conferences will also decrease as well as the number of international cooperation agreements. Similarly, European institutions funding research in universities may prefer to keep investments in the European Union to avoid taxes and problems that may arise from working with British universities after Brexit [28].

On the other hand, Germany has significantly focused on supporting sciences, and increased research budgets on federal government level in order to support the growth of new industries, such as renewable energy. This priority aligns with the fact that German Chancellor Angela Merkel holds a doctorate in quantum chemistry and has worked as a scientific researcher before getting involved in politics. Based on 2017 analysis published in Nature Magazine, researchers are attracted to come and work in Germany because it allocates a budget of EUR 4.6 billion for the Excellence Initiative, which has attracted almost 4000 foreign scientists to Germany since 2005. In 2016, German research organization, Deutsche Forschungsgemeinschaft (DFG), the main funding agency in Germany, allocated 2.9 EUR billion for research scholarships, which means the increasing probability of supporting research proposals with a considerable rate.

2018 list of top innovative European universities indicates that there is no relationship between the number of distinct universities in a given country and its size. For instance, Belgium has 7 universities listed, while it has a population of only 11 million. The same applies to Switzerland, Denmark, the Netherlands, and the Republic of Ireland. While Russia, the most populous country on the European continent and the fifth largest economy in Europe, does not have any universities in this list.

Either a university is ranked on the top or in the bottom of this list; the university remains among the top 100 universities in Europe. These universities are the source of original research and useful technologies that motivate and support the world economy. 


\subsection{Table of the Most Innovative Universities in Europe}

Table 4.1 shows the Europe's Most Innovative Universities in 2018 [28]. This is the most recent rankings when this book was composed. In order to unify with the rankings of
Asia-Pacific's ranking table, Table 4.1 stopped at 75 most innovative universities.

From Table 4.1, it is clear that the highest number of the Europe's Most Innovative Universities in 2018 is in Germany. In Table 4.2, the numbers of Europe's Most Innovative Universities in 2017 and 2018 in the different countries are given for comparison.
Table 4.1 Europe's most innovative universities in 2018

\begin{tabular}{|c|c|c|}
\hline Rank & Institution & Country \\
\hline 1 & KU Leuven & Belgium \\
\hline 2 & Imperial College London & UK \\
\hline 3 & University of Cambridge & UK \\
\hline 4 & Federal Institute of Technology in Lausanne (EPFL) & Switzerland \\
\hline 5 & University of Erlangen Nuremberg & Germany \\
\hline 6 & Technical University of Munich & Germany \\
\hline 7 & University of Manchester & UK \\
\hline 8 & University of Munich & Germany \\
\hline 9 & Technical University of Denmark & Denmark \\
\hline 10 & Swiss Federal Institute of Technology Zurich & Switzerland \\
\hline 11 & University College London & UK \\
\hline 12 & Delft University of Technology & Netherlands \\
\hline 13 & University of Zurich & Switzerland \\
\hline 14 & University of Oxford & UK \\
\hline 15 & University of Basel & Switzerland \\
\hline 16 & University of Montpellier & France \\
\hline 17 & Leiden University & Netherlands \\
\hline 18 & Pierre \& Marie Curie University_Paris 6 & France \\
\hline 19 & University of Paris Descartes-Paris 5 & France \\
\hline 20 & Ruprecht Karl University Heidelberg & Germany \\
\hline 21 & Johannes Gutenberg University of Mainz & Germany \\
\hline 22 & Free University of Berlin & Germany \\
\hline 23 & Eindhoven University of Technology & Netherlands \\
\hline 24 & University of Freiburg & Germany \\
\hline 25 & University of Paris Sud-Paris 11 & France \\
\hline 26 & Charité Medical University of Berlin & Germany \\
\hline 27 & Humboldt University of Berlin & Germany \\
\hline 28 & Grenoble Alpes University & France \\
\hline 29 & Dresden University of Technology & Germany \\
\hline 30 & University of Bordeaux & France \\
\hline 31 & Karlsruhe Institute of Technology & Germany \\
\hline 32 & University of Oslo & Norway \\
\hline 33 & Ghent University & Belgium \\
\hline 34 & University of Birmingham & UK \\
\hline 35 & University of Claude Bernard-Lyon 1 & France \\
\hline 36 & University of Glasgow & UK \\
\hline
\end{tabular}


Table 4.1 (continued)

\begin{tabular}{|c|c|c|}
\hline Rank & Institution & Country \\
\hline 37 & Queen Mary University London & UK \\
\hline 38 & King's College London & UK \\
\hline 39 & Technical University of Berlin & Germany \\
\hline 40 & RWTH Aachen University & Germany \\
\hline 41 & University of Strasbourg & France \\
\hline 42 & Free University of Brussels & Belgium \\
\hline 43 & University of Copenhagen & Denmark \\
\hline 44 & Polytechnic University of Milan & Italy \\
\hline 45 & University of Edinburgh & UK \\
\hline 46 & Grenoble Institute of Technology & France \\
\hline 47 & Vrije University of Brussels & Belgium \\
\hline 48 & Utrecht University & Netherlands \\
\hline 49 & Ecole Polytechnique & France \\
\hline 50 & Goethe University Frankfurt & Germany \\
\hline 51 & University of Paris Diderot-Paris 7 & France \\
\hline 52 & University of Munster & Germany \\
\hline 53 & Cardiff University & UK \\
\hline 54 & Catholic University of Louvain & Belgium \\
\hline 55 & Hannover Medical School & Germany \\
\hline 56 & Erasmus University Rotterdam & Netherlands \\
\hline 57 & University of Amsterdam & Netherlands \\
\hline 58 & University of Dundee & UK \\
\hline 59 & University of Aix-Marseille & France \\
\hline 60 & University of Leicester & UK \\
\hline 61 & Saarland University & Germany \\
\hline 62 & University of Sheffield & UK \\
\hline 63 & Eberhard Karls University of Tubingen & Germany \\
\hline 64 & Vienna University of Technology & Austria \\
\hline 65 & Trinity College Dublin & Ireland \\
\hline 66 & University of Milan & Italy \\
\hline 67 & University of Paul Sabatier-Toulouse III & France \\
\hline 68 & University of Leeds & UK \\
\hline 69 & University of Barcelona & Spain \\
\hline 70 & University of Southampton & UK \\
\hline 71 & University of Stuttgart & Germany \\
\hline 72 & University of Wurzburg & Germany \\
\hline 73 & University of Lorraine & France \\
\hline 74 & University of Geneva & Switzerland \\
\hline 75 & University of Twente & Netherlands \\
\hline
\end{tabular}


Table 4.2 Numbers of the Europe's most innovative universities in the different countries

\begin{tabular}{l|l|l}
\hline \multirow{2}{*}{ Countries } & \multicolumn{2}{|l}{$\begin{array}{l}\text { Numbers of the world's most } \\
\text { innovative universities }\end{array}$} \\
\cline { 2 - 3 } & 2017 & 2018 \\
\hline Germany & 18 & 20 \\
\hline UK & 15 & 16 \\
\hline France & 15 & 14 \\
\hline The Netherland & 7 & 7 \\
\hline Belgium & 5 & 5 \\
\hline Switzerland & 4 & 5 \\
\hline Denmark & 3 & 2 \\
\hline Italy & 3 & 2 \\
\hline Spain & 1 & 1 \\
\hline Ireland & 2 & 1 \\
\hline Norway & 1 & 1 \\
\hline Austria & 1 & 1 \\
\hline Total & $\mathbf{7 5}$ & 75 \\
\hline
\end{tabular}

Open Access This chapter is licensed under the terms of the Creative Commons Attribution 4.0 International License (http://creative commons.org/licenses/by/4.0/), which permits use, sharing, adaptation, distribution and reproduction in any medium or format, as long as you give appropriate credit to the original author(s) and the source, provide a link to the Creative Commons license and indicate if changes were made.
The images or other third party material in this chapter are included in the chapter's Creative Commons license, unless indicated otherwise in a credit line to the material. If material is not included in the chapter's Creative Commons license and your intended use is not permitted by statutory regulation or exceeds the permitted use, you will need to obtain permission directly from the copyright holder. 